\title{
ANALISIS TINGKAT PEMAHAMAN MAHASISWA AKUNTANSI TERHADAP KONSEP DASAR AKUNTANSI SETELAH PEMBERLAKUAN IFRS
}

(Studi Empiris Pada Mahasiswa Akuntansi Perguruan Tinggi Negeri di Pekanbaru)

Elisanovi

(Dosen Fekonsos UIN Suska Riau - Email : elisanovi97@yahoo.co.id)

\begin{abstract}
ABSTRAK
Tujuan penelitian ini adalah untuk melihat tingkat pemahaman mahasiswa yang beradal dari SMK jurusan Akuntansi, SMU jurusan IPS dan MA jurusan IPS tentang konsep dasar akuntansi setelah pemberlakuan IFRS dengan menggunakan variabel Aset, Kewajiban dan Ekuitas. Tehnik pengumpulan data menggunakan kuesioner, dengan menggunakan sampel sebanyak 90 orang mahasiswa Akuntansi S1 Universitas Riau dan UIN Suska Riau yang aktif pada smester III tahun akademik 2012/2013 dan telah lulus mata kuliah Pengantar Akuntansi 1 dan 2

Penelitian ini menggunakan uji beda Kruskal Wallis. Dari tiga variabel yang dijadikan pengukuran perbedaan tingkat pemahaman mahasiswa terhadap konsep dasar akuntansi yaitu aset, kewajiban dan ekuitas tidak terdapat perbedaan pemahaman mahasiswa terhadap konsep dasar akuntansi setelah pemberlakuan IFRS. Dari nilai mean rank ketiga variabel maka terlihat bahwa mahasiswa yang berasal dari Madrasah Aliyah lebih memahami konsep dasar akuntansi dibandingkan mahasiswa yang berasal dari SMK dan mahasiswa yang berasal dari SMA
\end{abstract}

Kata Kunci : Aset, Kewajiban,Ekuitas dan Mahasiswa Akuntansi

\section{PENDAHULUAN}

\section{Latar Belakang Masalah}

Pesatnya perkembangan ekonomi, perdagangan luar negeri, komunikasi, dan teknologi membuat pemanfaatan teknologi informasi akuntansi menjadi semakin luas dan canggih dalam berbagai bidang dan organisasi. Kemudian berkembanglah pengetahuanpengetahuan khusus di dalam seperangkat pengetahuan akuntansi, terlepas dari sudut pandang siapa pemakai laporan keuangan tersebut. Didalam praktik, keahlian dalam pengetahuan khusus ini menjadi spesialisasi pekerjaan di bidang akuntansi. Perkembangan ini kemudian menjadi dasar pemikiran dalam pengembangan kurikulum pendidikan akuntansi.

Akuntansi merupakan salah satu jurusan di Fakultas Ekonomi yang banyak diminati oleh mahasiswa saat ini. Dari hasil penelitian Basuki dalam (Ariani, 2004) menyebutkan bahwa ratarata mahasiswa memilih jurusan akuntansi, didorong oleh keinginan mereka untuk menjadi profesional di bidang akuntansi. Selain itu mereka juga termotivasi oleh anggapan bahwa akuntan di masa mendatang akan sangat dibutuhkan oleh banyak 
organisasi dan perusahaan, khususnya di Indonesia.

Menurut Budhiyanto dan Ika Paskah (2004), tingkat pemahaman akuntansi mahasiswa dinyatakan dengan seberapa mengerti seorang mahasiswa terhadap apa yang sudah dipelajari yang dalam konteks ini mengacu pada mata kuliah akuntansi dan Indeks Prestasi Kumulatif (IPK). Tanda seorang mahasiswa memahami akuntansi tidak hanya ditujukan dari nilai-nilai yang didapatkannya dalam mata kuliah tetapi juga apabila mahasiswa tersebut mengerti dan dapat menguasai konsepkonsep yang terkait.

Pada semester awal, setiap perguruan tinggi mewajibkan mahasiswa jurusan akuntansi untuk mengikuti perkuliahan Akuntansi Pengantar. Sebagai mata kuliah yang diajarkan pada semester pertama di tahun pertama, tidak disangsikan lagi mata kuliah ini memegang peranan penting dan menentukan dalam mengantarkan para mahasiswa yang akan mempelajari akuntansi dan mata kuliah lain yang berkaitan pada tahapan berikutnya. Sebagai mata kuliah pengantar, mata kuliah ini dimaksudkan untuk memberikan pengetahuan dasar atau fundamen kepada para mahasiswa. Oleh karena itu bangunan pengetahuan akuntansi yang dimiliki mahasiswa kelak, akan banyak dipengaruhi oleh keberhasilan pembelajaran mata kuliah ini sebagai fundamennya.

Menurut Munawir (2004) ada tiga materi pokok tentang konsep dasar akuntansi yang harus dikuasai oleh mahasiswa akuntansi dalam kuliah Akuntansi Pengantar, yaitu pemahaman tentang aktiva, Kewajiban, dan modal. Dari ketiga materi tersebut mahasiswa diharapkan dapat mengikuti perkuliahan dengan baik dan benar karena dengan penguasaan yang baik terhadap aktiva, kewajiban, dan modal akan mempermudah mahasiswa untuk memahami semua masalah-masalah yang akan ditemui dalam akuntansi. Mahasiswa akuntansi memandang mata kuliah Akuntansi Pengantar sebagai mata kuliah pokok yang akan memberi landasan penting dan memberi pengaruh yang besar pada keberhasilan mereka dalam menempuh mata kuliah akuntansi lain yang akan ditempuh pada tahuntahun berikutnya.

Dengan demikian hendaknya pengetahuan akuntansi mahasiswa yang berasal dari SMK Jurusan Akuntansi sudah pasti lebih besar apabila dibandingkan dengan mahasiswa yang berasal dari SMA dan Madrasah Aliyah. Sederhananya penelitian ini diharapkan dapat membuktikan apakah perbedaan latar belakang sekolah tersebut berdampak terhadap pemahaman mahasiswa akuntansi akan konsep dasar akuntansi di perguruan tinggi.

International Financial

Reporting Standarts (IFRS), mengatur empat hal utama yaitu bagaimana mengatur dan mengukur suatu transaksi serta penyajian dan pengungkapan dari transaksi itu sendiri. Melalui IFRS laporan mengenai posisi keuangan dan rugi laba suatu perusahaan bisa didapatkan dengan mudah dan pengaruhnyapun sangat netral. Dengan dimulainya pemberlakuan IFRS pada tahun 2012 ini, diharapkan mahasiswa juga mendapatkan pemahaman yang lebih baik tentang konsep dasar akuntansi setelah pemberlakuan IFRS ini.

\section{Perumusan Masalah}

1. Apakah terdapat perbedaan secara signifikan terhadap pemahaman 
tentang aset dan seberapa besar pemahaman tentang aset antara mahasiswa berasal dari SMK Jurusan Akuntansi, SMA Jurusan IPS dan Madrasah Aliyah Umum?

2. Apakah terdapat perbedaan secara signifikan terhadap pemahaman tentang kewajiban dan seberapa besar pemahaman tentang kewajiban antara mahasiswa berasal dari SMK Jurusan Akuntansi, SMA Jurusan IPS dan Madrasah Aliyah Umum?

3. Apakah terdapat perbedaan secara signifikan terhadap pemahaman tentang ekuitas dan seberapa besar pemahaman tentang ekuitas antara mahasiswa berasal dari SMK Jurusan Akuntansi, SMA Jurusan IPS dan Madrasah Aliyah Umum?

\section{Tujuan Penelitian}

1. Untuk mengetahui apakah terdapat perbedaan secara signifikan terhadap pemahaman tentang aset dan seberapa besar pemahaman tentang aset antara mahasiswa berasal dari SMK Jurusan Akuntansi, SMA Jurusan IPS dan Madrasah Aliyah Umum?

2. Untuk mengetahui apakah terdapat perbedaan secara signifikan terhadap pemahaman tentang kewajiban dan seberapa besar pemahaman tentang kewajiban antara mahasiswa berasal dari SMK Jurusan Akuntansi, SMA Jurusan IPS dan Madrasah Aliyah Umum?

3. Untuk mengetahui apakah terdapat perbedaan secara signifikan terhadap pemahaman tentang ekuitas dan seberapa besar pemahaman tentang ekuitas antara mahasiswa berasal dari SMK Jurusan Akuntansi, SMA Jurusan IPS dan Madrasah Aliyah Umum?

\section{Pengertian Pendidikan}

Pendidikan

merupakan

pengaruh lingkungan terhadap individu untuk menghasilkan perubahan- perubahan yang tetap dalam kebiasaan perilaku, pikiran dan sikapnya. Pendidikan formal adalah pendidikan di sekolah/perguruan tinggi yang berlangsung secara teratur dan bertingkat mengikuti syarat-syarat yang jelas dan ketat. Tujuan pendidik adalah untuk memperkaya budi pekerti, pengetahuan dan untuk menyiapkan seseorang agar mampu dan trampil dalam suatu bidang pekerjaan tertentu.

Menurut Wina (2005) dalam model pembelajaran konvensional mahasiswa ditempatkan sebagai objek belajar yang berperan sebagai penerima informasi secara pasif dan mahasiswa lebih banyak belajar secara individual dengan menerima, mencatat, dan menghafal materi. Metode konvensional lebih menekankan pada metode ceramah, metode ceramah adalah penuturan bahan perkuliaha secara lisan (Nana, 2005).

\section{Pengertian Akuntansi}

Menurut Munawir (2004), Akuntansi adalah seni daripada pencatatan, penggolongan dan peringkasan pada peristiwa-peristiwa dan kejadian-kejadian yang setidaktidaknya sebagian bersifat keuangan dengan cara yang setepat-tepatnya dan dengan petunjuk atau dinyatakan dalam uang, serta penafsiran terhadap hal-hal yang timbul daripadanya .

Sedangkan menurut Niswonger (1999) akuntansi adalah sistem informasi 
yang memberikan laporan kepada pihakpihak berkepentingan mengenai kegiatan ekonomi dan kondisi perusahaan.

Sementara Weygandt (2012) mendefenisikan ; accounting is the financial information system that provides these insights. In short, ti understand organization to interested users.

Dari defenisi akuntansi tersebut di ketahui bahwa tujuan akuntansi adalah menghasilkan adalah pelaporan dari peristiwa-peristiwa keuangan perusahaan yang dapat diartikan sebagai laporan keuangan. Jadi laporan keuangan menurut Myer dalam (Munawir, 2004) adalah : Dua daftar yang disusun oleh Akuntan pada akhir periode untuk suatu perusahaan. Kedua daftar itu adalah daftar Neraca atau Daftar Pendapatan atau Daftar Rugi Laba. Pada waktu akhir-akhir ini sudah menjadi kebiasaan bagi perseroanperseroan untuk menambah daftar ketiga yaitu Daftar Surplus atau Daftar Laba yang tidak dibagikan/laba yang ditahan (Munawir, 2004).

\section{Konsep Dasar Pemahaman Akuntansi}

Konsep dasar pemahaman akuntansi menurut Munawir, (2004) terdiri dari tiga bagian utama yaitu aset, hutang dan ekuitas

\section{Aset}

Manfaat ekonomi masa depan yang terwujud dalam aset adalah potensi dari aset tersebut untuk memberikan sumbangan, baik langsung maupun tidak langsung, arus kas dan setara kas kepada perusahaan. Potensi tersebut dapat berbentuk sesuatu yang produktif dan merupakan bagian dari aktifitas operasional perusahaan. Mungkin pula berbentuk sesuatu yang dapat diubah menjadi kas atau setara kas atau berbentuk kemampuan untuk mengurangi pengeluaran kas, seperti penurunan biaya akibat penggunaan proses produksi alternative. (PSAK-KDPPLK;53).

Manfaat ekonomi masa depan yang terwujud dalam aset dapat mengalir ke dalam perusahaan dengan beberapa cara, misalnya;

a. Digunakan baik sendiri maupun bersama aset lain dalam produksi barang dan jasa yang dijual oleh perusahaan.

b. Dipertukarkan dengan aset lain

c. Digunakan untuk menyelesaikan kewajiban;atau

d. Dibagikan kepada para pemilik perusahaan. (PSAK KDPPLK;55)

Dalam pengertian, aset tidak terbatas pada kekayaan perusahaan yang berwujud saja, tetapi juga termasuk pengeluaran-pengeluaran yang belum dialokasikan (deffered changes) atau biaya yang masih harus dialokasikan pada penghasilan yang akan datang, serta aktiva yang tidak berwujud lainnya (intangible asset) misalnya goodwill, hak paten, hak menerbitkan dan sebagainya.

\section{1) Aset Lancar}

Current assets are assets that a company expect to convert to cash or use up within one year (Weygandt; 2012) .Sedangkan menurut Standar Akuntansi Keuangan, aset adalah sumber daya yang dikuasai oleh perusahaan sebagai akibat dari peristiwa masa lalu dan ari mana manfaat ekonomi di masa depan diharapkan akan diperoleh perusahaan.

Berdasarkan Pernyataan Standar Akuntansi Keuangan, suatu aset diklasifikasikan sebagai aset lancar, jika aset tersebut ;

a. Diperkirakan akan direalisasi atau dimiliki untuk dijual atau digunakan dalam jangka waktu siklus operasi normal perusahaan;atau

b. Dimiliki untuk diperdagangkan atau 
untuk tujuan jangka pendek dan diharapkan akan direalisasi dalam jangka waktu dua belas bulan dari tanggal neraca;atau

c. Berupa kas atau setara kas yang penggunaannya tidak dibatasi.

Dengan demikian, dapat diketahui bahwa elemen-elemen yang termasuk dalam aktiva lancar antara lain :

1. Kas, uang yang tersedia untuk operasi perusahaan baik yang ada dalam perusahaan sendiri maupun ditempat lain atau sesuatu yang dapat dipersamakan dengan uang kas. Kas meliputi koin, uang kertas, cek, wesel (money order atau kiriman uang melalui pos yang lazim berbentuk draft bank atau cek bank; hal ini untuk selanjutnya diistilahkan dengan wesel saja), uang yang disimpan di bank yang dapat ditarik tanpa pembatasan dari bank yang bersangkutan. Menurut PSAK, kas terdiri atas saldo kas (cash on hand) dan rekening giro. Sedangkan setara kas (cash equivalent) adalah investasi yang sifatnya agak likuid, berjangka pendek, dan yang dengan cepat dapat dijadikan kas dalam jumlah tertentu tanpa menghadapi resiko perubahan nilai yyang signifikan.

2. Persediaan, yaitu meliputi barangbarang yang nyata dimiliki untuk dijual kembali baik harus melalui proses produksi dahulu maupun langsung dalam suatu periode operasi normal perusahaan. Menurut PSAK 14;03, persediaan adalah aset;
a. Tersedia untuk dijual normal dalam kegiatan usaha
b. Dalam proses produksi dan atau dalam perjalanan;atau
c. Dalam bentuk bahan atau

perlengkapan (supplies) untuk digunakan dalam proses produksi atau pemberian jasa

3. Piutang, baik piutang dagang maupun piutang wesel. Account receivables are amount owed by customers on.account. They result from the sale of goods and services. (Weygandt;2012).

4. Piutang lainnya yang belum tertagih sampai pada akhir periode akuntansi.

5. Semua investasi sementara.

6. Semua beban/biaya yang dilakukan dimuka dan masih merupakan piutang pada akhir periode Akuntansi.

\section{2) Aset Tetap}

Merupakan aset perusahaan yang tidak dimaksudkan untuk diperjualbelikan melainkan untuk digunakan dalam kegiatan perusahaan yang umurnya lebih dari satu tahun dan merupakan pengeluaran perusahaan dalam jumlah yang relatif besar.

Berdasarkan PSAK 16, aset tetap adalah aset berwujud yang;

a. dimiliki untuk digunakan dalam produksi atau penyediaan barang atau jasa, untuk direntalkan kepada pihak lain, atau untuk tujuan administrative; dan

b. diharapkan untuk digunakan selama lebih dari satu periode.

Biaya perolehan aset tetap harus diakui sebagai aset jika dan hanya jika;

a. besar kemungkinan manfaat ekonomis di masa depan berkenaan dengan aset tersebut akan mengalir ke entitas;dan 
b. biaya perolehan aset dapat diukur secara andal

Menurut Weygandt, plant assets are resources that have three characteristics; They have a physical substance (a definite size and shape), are used in the operation of busimess, and are not intended for sale to customers. They are also called property, plant and equipment; plant equipment and fixed assets.

\section{3) Aset Tetap Tidak Berwujud}

Yaitu aset yang tidak mempunyai sifat-sifat fisik tetapi mempunyai kegunaan. Seperti Hak Paten, Copyright, Organization cost atau Biaya pendirian Francise, Good will, dan sebagainya.

Intangible assets are right, privilages, and competitive advantages that results from the ownership of longlived assets that do not possess physical substance. Evidence of intangibles may exist in the form of contacts or licenses. Intangibles may arise from the following sources;

a. Government grants, such as patents, copyright, and trade marks

b. Acquisition of another business, in which the purchase price includes a payment for the company's favourable attributes (called goodwill)

c. Private monopolistic arrangements arising from contractual agreement, such as franchises and leases. (Weygandt;2012)

4) Beban / Biaya Yang Ditangguhkan

Biaya yang dibayar dimuka (Prepaid Expenses) dan biaya yang ditangguhkan (Deferred Charge) merupakan biaya-biaya yang telah dikeluarkan akan tetapi mempunyai kegunaan atau menjadi beban tahuntahun yang akan datang.

5) Aset Lain-Lain

Ialah semua aktiva perusahaan yang tidak dapat digolongkan dalam aktiva tersebut diatas, misalnya mesin- mesin yang tidak dapat dipakai lagi.

\section{Utang}

Utang adalah semua kewajiban keuangan perusahaan kepada pihak lain yang belum terpenuhi, dimana hutang ini merupakan sumber dana atau modal perusahaan yang berasal dari kreditur. Utang atau kewajiban perusahaan dapat dibedakan ke dalam utang lancar (utang jangka pendek) dan utang jangka panjang (Munawir, 2004).

Utang lancar ialah semua kewajiban keuangan yang harus di penuhi dalam satu periode operasi normal dan yang termasuk dalam hutang lancar. Sedangkan macam-macam utang antara lain :

a. Utang Dagang (Account Payable)

b. Wesel Bayar (Note Payable)

c. Utang yang timbul karena jasa-jasa yang sudah diterima tetapi belum dibayar (Accrued Expenses).

d. Utang atau Kewajiban Bersyarat (Contingent Liabilities)

e. Pendapatan Yang Diterima Dimuka ialah semua penerimaan-penerimaan yang telah diterima tahun berjalan tetapi bukan merupakan penghasilan tahun berjalan sampai dengan akhir periode.

f. Utang-utang Jangka Panjang ialah semua kewajiban yang akan dilunasi dalam jangka waktu lebih dari satu tahun.

g. Utang-utang Lainnya ialah semua kewajiban yang tidak dapat digolongkan kedalam utang lancar maupun utang jangka panjang. 
Perjanjian utang dapat dikelompokkan ke dalam dua bentuk, kadang mengacu sebagai perjanjian negatif dan positif (Janes, 2003).

1. Perjanjian negatif umumnya menunjukkan aktivitas tertentu yang mengakibatkan substitusi aset atau masalah pembayaran kembali. Contoh perjanjian utang negatif mencakup larangan terhadap merger, batasan peminjaman tambahan, batasan pembayaran dividen dan excess cash sweeps.

2. Perjanjian positif mensyaratkan peminjam melakukan tindakan tertentu, seperti menjaminkan aset atau memenuhi benchmark tertentu (biasanya rasio-rasio keuangan) yang mengindikasikan kesehatan keuangan. Contoh umum perjanjian utang positif mencakup tingkat rasio current, leverage, probabilitas dan net worth minimal atau maksimum.

Utang yang dipergunakan secara efektif dan efisien akan meningkatkan nilai perusahaan (Herry dan Hamin, 2005) menunjukkan bahwa leverage menyebabkan peningkatan nilai perusahaan (value enchancing).

\section{Ekuitas}

Adalah merupakan hak atau bagian yang dimiliki oleh pemilik Perusahaan yang ditunjukkan dalam pos modal (modal saham), surplus dan laba yang ditahan. Atau kelebihan nilai aktiva yang dimiliki oleh perusahaan terhadap seluruh hutang-hutangnya (Munawir, 2004).

a) Modal Sendiri

Dalam perusahaan yang berbentuk perusahaan terbatas, modal dapat diklasifikasikan antara lain :

1. Modal yang disetor (modal saham, tambahan modal disetor / agio saham, hadiah / donasi).

2. Laba yang ditahan (Retained Earning). Retained earning is net income that a company retains for use in the business. The balance in retained earnings is part of the sharholders'claim on the total assets of the corporation. (Weygandt;2012).

3. Modal Penilaian (Appraisal Capital).

\section{Review Penelitian Terdahulu}

Penelitian yang sama pernah dilakukan oleh beberapa peneliti sebelumnya. Penelitian yang dilakukan oleh Sar'i, Irsadsyah, dan Djamil (2010) bertujuan untuk mengukur perbedaan pemahaman dan seberapa besar pemahaman mahasiswa yang berasal dari SMK Jurusan Akuntansi, SMA Jurusan IPS, dan Madrasah Aliyah Umum terhadap konsep dasar akuntansi. Untuk sampel yang digunakan adalah mahasiswa semester 3 jurusan akuntansi S1 UIN Suska Riau yang aktif untuk tahun ajaran 2009/2010 yang berasal dari SMK Jurusan Akuntansi, SMA Jurusan IPS, dan Madrasah Aliyah Umum dan alat analisis yang digunakan adalah uji Kruskal Wallis.

Hasil penelitian menyatakan hanya satu variabel yang dinyatakan terdapat perbedaan pemahaman mahasiswa terhadap konsep dasar akuntansi tentang modal. Disamping itu tidak terdapat perbedaan pemahaman mahasiswa terhadap konsep dasar akuntansi tentang aktiva dan kewajiban. Dari nilai mean rank diketahui mahasiswa yang berasal dari Madrasah Aliyah lebih memahami konsep dasar akuntansi dibandingkan mahasiswa yang berasal dari SMK dan mahasiswa yang berasal dari SMA.

Penelitian yang dilakukan oleh Novius (2010) yang bertujuan untuk membuktikan secara empiris tentang kemampuan mahasiswa yang berasal dari 
SMK Jurusan Akuntansi, SMA Jurusan IPS dan Madrasah Aliyah Umum dalam memahami mata kuliah pengantar akuntansi. Dasar-dasar akuntansi yang dijadikan sebagai variabel dalam penelitian ini yaitu aktiva, kewajiban dan modal dengan sampel sebanyak 60 orang mahasiswa Jurusan Akuntansi S1 UIN Suska Riau yang terdaftar sebagai mahasiswa semester 3 , 5, dan 7 yang aktif untuk tahun ajaran 2009/2010 dan telah menyelesaikan mata kuliah pengantar akuntansi 1 dan 2. Hasil penelitian menunjukkan bahwa tidak terdapat perbedaan secara signifikan terhadap pemahaman tentang aktiva, kewajiban dan modal antara mahasiswa yang berasal dari SMK Jurusan Akuntansi, SMA Jurusan IPS dan Madrasah Aliyah Umum.

Selanjutnya penelitian yang sama juga dilakukan oleh M. Cholid Mawardi dari Fakultas Ekonomi Universitas Islam (UNISMA) Malang dengan judul Analisis Tingkat Pemahaman Mahasiswa Akuntansi terhadap Konsep Dasar Akuntansi di Perguruan Tinggi Negeri di Kota Malang. Hasil penelitian menunjukkan tidak terdapat pemahaman mahasiswa terhadap konsep dasar akuntansi. Dari nilai mean rank ketiga variabel maka terlihat bahwa mahasiswa yang berasal dari Madrasah Aliyah lebih memahami konsep dasar akuntansi dibandingkan mahasiswa yang berasal dari SMK dan SMA.

\section{Model Penelitian}

\begin{tabular}{ccc}
\multicolumn{2}{c}{ Perbedaan } & mahasiswa \\
akuntansi yang berasal dari latar
\end{tabular} belakang sekolah yang berbeda akan pemahaman dasar-dasar akuntansi seperti yang tergambar dalam model penelitian berikut ini :

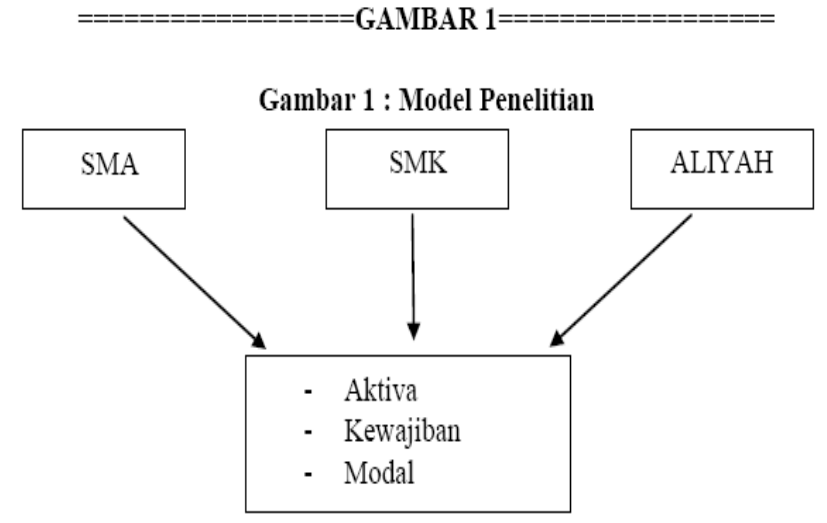

Hipotesis Penelitian

H1. Terdapat perbedaan secara signifikan terhadap tingkat pemahaman aset antara mahasiswa berasal dari SMK Jurusan Akuntansi, SMA
Jurusan IPS dan Madrasah Aliyah Umum.

H2. Terdapat perbedaan secara signifikan terhadap tingkat pemahaman kewajiban antara mahasiswa berasal dari SMK 
Jurusan Akuntansi, SMA Jurusan IPS dan Madrasah Aliyah Umum.

H3. Terdapat perbedaan secara signifikan terhadap tingkat pemahaman ekuitas antara mahasiswa berasal dari SMK Jurusan Akuntansi, SMA Jurusan IPS dan Madrasah Aliyah Umum.

\section{Metodologi Penelitian \\ Populasi dan Sampel}

Penelitian ini termasuk penelitian empiris (empirical research) Penelitian ini memerlukan kehadiran peneliti untuk melakukan observasi terhadap fakta atau segala sesuatu yang dialaminya tanpa perantara orang lain. Menurut tujuan studi, penelitian ini merupakan penelitian untuk menguji hipotesis (Indiantoro dan Supomo, 1999).
Menurut Sugiyono (2005) populasi adalah wilayah generalisasi yang terdiri atas : objek/subjek yang mempunyai kualitas dan karakteristik tertentu yang oleh peneliti untuk dipelajari dan kemudian ditarik kesimpulan.

Populasi dalam penelitian ini berjumlah 819 mahasiswa jurusan akuntansi yang berasal dari Perguruan Tinggi Negeri di Pekanbaru yang terdaftar sebagai mahasiswa aktif untuk ajaran 2012/2013 dan telah menyelesaikan mata kuliah pengantar akuntansi I, pengantar akuntansi II. Populasi tersebut terdiri dari : mahasiswa Universitas Riau dan Universitas Islam Negeri Sultan Syarif Kasim Riau

Gambaran dari jumlah populasi dalam penelitian ini dapat dilihat pada tabel III.1 berikut ini:

Tabel 1: Jumlah Mahasiswa Smester III Jurusan Akuntansi S1

Pada Perguruan Tinggi Negeri di Pekanbaru

Tahun Akademis 2012/2013

\begin{tabular}{|l|l|l|l|l|}
\hline No & \multicolumn{1}{|c|}{ Asal Sekolah } & \multicolumn{1}{c|}{ UIN SUSKA } & \multicolumn{1}{c|}{ UR } & Jumlah \\
\hline 1 & SMA & 41 & 266 & 307 \\
\hline 2 & SMK & 129 & 257 & 386 \\
\hline 3 & MAN & 27 & 83 & 110 \\
\hline 4 & Lainnya & 4 & 12 & 16 \\
\hline & TOTAL & 201 & 618 & 819 \\
\hline
\end{tabular}

Sumber: Jurusan Akuntansi S1 UIN SUSKA Riau dan UR, 2012

Penentuan jumlah sampel dilakukan dengan menggunakan rumus Slovin dalam Umar (2002) sebagai berikut:

Keterangan :

$\mathrm{n}:$ Jumlah sampel

$\mathrm{N}$ : jumlah populasi

e : Nilai kritis (batasan ketelitian) yang diinginkan (persen kelonggaran ketidaktelitian karena pengambilan sampel populasi) sebesar $10 \%$.

Jadi jumlah sampel dalam penelitian ini adalah: 


$$
\begin{aligned}
& . \mathrm{n}=819 \\
& \text {------------------- } \\
& 1+819(10 \%) \\
& \mathrm{n}=819 \\
& 1+8,19 \\
& . n=89,11 \\
& . \mathrm{n}=90
\end{aligned}
$$

Setelah melakukan perhitungan dengan menggunakan rumus Slovin, maka diketahui sampel sebanyak 90 sampel (mahasiswa).

Dari tabel III.1 terlihat bahwa jumlah total mahasiswa semester III yang aktif pada perguruan tinggi negeri di Pekanbaru yaitu Universitas Riau dan Universitas Islan Negeri Sultan Syarif Kasim untuk tahun ajaran 2012/2013 adalah 819 orang. Sedangkan yang dijadikan sampel dalam penelitian ini adalah 90 orang mahasiswa semester 3 yang aktif untuk tahun ajaran 2012/2013 dan berasal dari SMK Jurusan Akuntansi, SMA Jurusan IPS dan Madrasah Aliyah Umum. Pemilihan sampel mahasiswa semester 3 diharapkan agar penelitian ini memperoleh hasil yang optimal dengan pertimbangan bahwa mahasiswa telah menjalani waktu pendidikan yang sama.

\section{Jenis dan Sumber Data}

Penelitian ini menggunakan sumber data primer (primary data) merupakan sumber data penelitian yang diperoleh secara langsung dari sumber asli (tidak melalui perantara) dan secara khusus dikumpulkan oleh peneliti untuk menjawab pertanyaan penelitian (Indriantoro dan Supomo, 1999).
Sumber data primer yang digunakan dalam penelitian ini adalah hasil penyebaran kuisioner atau angket yang diberikan secara langsung. Sedangkan Metode pengumpulan data dalam penelitian ini adalah dengan menggunakan metode kuisioner

\section{Metode Analisis Data}

Metode analisis data yang digunakan untuk menguji hipotesis dalam penelitian ini yaitu menggunakan uji data tiga sampel (independen) yang tidak berhubungan yaitu uji Kruskall Wallis. Sebelum dilakukan uji kruskall wallis, terlebih dahulu dilakukan uji kualitas dan normalitas data. Pengujian kualitas data dilakukan dengan dua cara, yaitu validitas dan realibilitas. Untuk memilih data yang instrumen penelitian yang dapat diandalkan kemampuannya, maka harus dilakukan uji validitas dan uji realibilitas terhadap alat ukur tersebut supaya diperoleh representatif dalam penelitian.

\section{Uji Validitas}

Indriantoro \& Supomo (2002) mengemukakan bahwa validitas data penelitian ditentukan oleh proses pengukuran data yang akurat. Oleh karena itu, jika ada sinonim dari realibilitas yang paling tepat adalah akurasi. Suatu instrumen pengukuran 
dikatakan valid jika instrumen tersebut mengukur apa yang seharusnya diukur. Dengan perkataan lain instrumen tersebut dapat mengukur construct sesuai dengan yang diharapkan oleh peneliti. Menurut Kaiser dan Rice (1974), untuk menunjukkan Construct Validity dari masing-masing variabel, maka nilai Kaiser Meyer Olkin Measure Of Sampling Adequacy (Kaiser MSA) mengisyaratkan agar data yang terkumpul dapat tepat dilakukan analisis faktor nilainya minimal 0,50. Adapun teknik validitas yang dilakukan melalui analisis butir soal dengan bantuan program komputer SPSS 17 For Windows.

\section{Uji Realibilitas}

Realibilitas mengarah pada suatu pengertian bahwa suatu instrumen cukup dapat digunakan sebagai alat pengumpul data, karena instrumen tersebut sudah baik (Arikunto, 1998). Uji realibilitas menunjukkan sejauh mana suatu hasil pengukuran relatif konsisten apabila Dimana :

$\mathrm{K}=$ nilai Kruskal-Wallis dari hasilperhitungan

$\mathrm{Ri}=$ jumlah rank dari kategori/perlakuan ke $\mathrm{i}$

$\mathrm{Ni}$ = Banyaknya ulanganpada kategori/perlakuan ke-i

$\mathrm{K}=$ banyaknya kategori/perlakuan $(\mathrm{i}=1,2,3, \ldots ., \mathrm{k})$

$\mathrm{N}=$ Jumlah seluruh data $(\mathrm{N}=\mathrm{n} 1+\mathrm{n} 2+\mathrm{n} 3+\ldots \ldots \ldots .+\mathrm{nk})$

Kriteria penerimaan Ho adalah sebagai berikut :

a. Jika Statistik Hitung < Statistik Tabel, maka Ho diterima.

b. Jika Statistik Hitung > Statistik Tabel, maka Ho ditolak.

\section{Pengujian Hipotesis}

Pengujian hipotesis dalam penelitian ini yaitu menggunakan uji data tiga sampel (independen) yang tidak berhubungan yaitu uji Kruskal Wallis yaitu untuk mengetahui perbedaan pemahaman tentang aset, kewajiban dan ekuitasl antara mahasiswa berasal dari SMK Jurusan Akuntansi, SMA Jurusan IPS dan pengukuran dilakukan beberapa kali. Teknik yang digunakan untuk mengukur realibilits (keandalan) dalam penelitian ini adalah teknik Cronbach Alpha. Instrumen yang dipakai dalam variabel tersebut dikatakan andal (realible), apabila memiliki nilai Cronbach Alpha lebih dari 0,6 (Nunnaly, 1978) dalam Wahyuni (2006). Sedangkan uji normalitas menggunakan ujiKormogorov Smirnov (One-Sample Kolmogorov-Smirnov Test).

\section{Uji Kruskal Wallis}

Uji Kruskal wallis adalah uji nonparametrik yang digunakan untuk membandingkan tiga atau lebih kelompok data sampel. Penyusunan hipotesis dalam uji Kruskal Wallis adalah sebagai berikut:

HO : sampel berasal dari populasi yang sama $(\mu 1=\mu 2=\ldots=\mu \mathrm{k})$

Ha : sampel berasal dari populasi yang berbeda $(\mu \mathrm{i}=\mu \mathrm{j})$

Rumus umum yang digunakan pada uji kruskal wallis adalah :
Madrasah Aliyah Umum yang dilihat dari nilai signifikansi (Santoso, 2004).

Cara pengambilan keputusan adalah :

Jika nilai probabilitas $>0,05$

maka hipotesis diterima

Jika nilai probabilitas $<0,05$

maka hipotesis ditolak

\section{Hasil Penelitian dan Pembahasan}




\section{Statistik Deskriptif Penelitian}

Penelitian ini dilakukan selama bulan September sampai dengan Oktober 2012 dengan menyebar kuesioner kepada sampel penelitian yang berjumlah 90 orang. Kuesioner diberikan langsung kepada responden dan tidak diperbolehkan membawa pulang karena penelitian ini mengukur kemampuan mahasiswa secara langsung akan pemahamannya terhadap konsep- konsep dasar akuntansi. Alasan ini sengaja dibuat agar responden tidak mencari referensi sebagai jawaban sewaktu mengisi kuesionernya.

Tingkat

pengumpulan kuesioner, dapat dilihat pada tabel IV. 1 dibawah ini :

Tabel 1

Tingkat Pengembalian Kuesioner

\begin{tabular}{|l|c|c|c|c|c|c|}
\hline \multirow{2}{*}{ Keterangan } & SMK & \multicolumn{2}{c|}{ SMA } & \multicolumn{2}{c|}{ ALIYAH } \\
\cline { 2 - 9 } & Jumlah & \% & Jumlah & \% & Jumlah & \% \\
\hline Total kuesioner yang disebarkan & 42 & 47 & 34 & 38 & 14 & 15 \\
\hline Total kuesioner yang tidak terkumpul kembali & - & - & - & - & 3 & 3 \\
\hline Total kuesioner yang terkumpul kembali & 42 & 47 & 34 & & 11 & 12 \\
\hline Total kuesioner yang tidak dapat diolah & - & - & - & - & - & - \\
\hline Total kuesioner yang dapat diolah & 42 & 47 & 34 & - & 11 & 12 \\
\hline
\end{tabular}

Berdasarkan dari tabel IV.1 dapat dijelaskan secara rinci bahwa tingkat pengumpulan kuesioner sebagai berikut :

1. Kepada mahasiswa yang berasal dari SMK, peneliti menyebarkan sebanyak 42 buah kuesioner atau $47 \%$ dari jumlah sampel. Seluruh kuesioner yang disebarkan kembali dan seluruh kuesioner tersebut dapat diolah. Jadi total kuesioner yang dapat diolah dari jumlah keseluruhan kuesioner yang disebarkan adalah 42 buah atau $100 \%$ dari jumlah sampel yang berasal dari SMK.

2. Kepada mahasiswa yang berasal dari SMA, peneliti menyebarkan sebanyak 34 buah kuesioner atau $38 \%$ dari kesaluruhan jumlah sampel. Seluruh kuesioner yang disebar kembali dan seluruh kuesioner yang kembali dapat diolah. Jadi total kuesioner yang dapat diolah dari jumlah keseluruhan kuesioner yang disebarkan adalah 34 buah atau $100 \%$ dari jumlah sampel yang berasal dari SMA.

3. Kepada mahasiswa yang berasal dari Madrasah Aliyah, peneliti menyebarkan sebanyak 14 buah kuesioner atau $15 \%$ dari seluruh jumlah sampel. Seluruh kuesioner yang disebar kembali dan dapat diolah. Jadi total kuesioner yang dapat diolah dari jumlah keseluruhan kuesioner yang disebarkan adalah 14 buah atau $100 \%$ dari jumlah sampel yang berasal dari Aliyah.

Dengan demikian maka total kuesioner yang dapat diolah dari 
jumlah sampel penelitian adalah sebanyak 90 buah kuesioner atau 100\%. Dalam penelitian ini objek penelitian sudah terpenuhi, karena pada periode tersebut proses belajar mengajar baru saja dimulai sehingga tidak ditemukan kesulitan dalam menyebarkankan dan mengumpulkan kembali kuesioner tersebut. Dengan demikian, diharapkan dari 90 orang mahasiswa yang dijadikan sampel penelitian akan mewakili jawaban dari teman-teman mereka yang tidak termasuk kedalam sampel penelitian ini.

Statistik deskriptif untuk variabel aktiva memiliki nilai rata-rata sebesar
3,9330 dengan nilai minimum sebesar 2,20 dan nilai maksimum 5,00, sedangkan standar deviasinya sebesar 0,62086 . Variabel kewajiban memiliki nilai rata-rata 4,0130 dengan nilai minimum 2,20 dan nilai maksimum5,00, sedangkan standar deviasinya sebesar 0,54414 . Variabel modal diperoleh nilai rata-rata 3,7330 dengan nilai minimum 2,10 dan nilai maksimum 4,90, sedangkan standar deviasinya sebesar 0,56462 .

Hasil pengujian validitas dan realibilitas yaitu sebagai berikut:

\section{Tabel}

\section{Hasil Uji Validitas dan Realibilitas Data}

Variabel

KMO

ASET

KEWAJIBAN

EKUITAS

\begin{tabular}{cc}
\multicolumn{2}{c}{ Validitas } \\
Keputusan \\
0,878 & Valid \\
0.825 & Valid \\
0,772 & Valid
\end{tabular}

Cronbach'alpa

0.872

0.863

0.814

\section{Realibilitas}

Keputusan
Reliabel
Reliabel
Reliabel

Berdasarkan tabel diatas dapat dijelaskan bahwa hasil uji realibilitas dan validitas terhadap 90 sampel yang diukur dengan 30 item pertanyaan yang terdiri dari :

1. Variabel aset diukur dengan 10 item pertanyaan. Setelah dilakukan uji realibilitas, nilai Cronbach alpha adalah 0,872 yang berarti variabel tersebut reliabel, karena memiliki Cronbach alpha diatas 0,60. Hasil uji validitas menunjukkan bahwa instrumen penelitian variabel aset memiliki KMOMSA sebesar 0,878, karena nilai KMOMSA pada instrumen variabel aset > 0.05 maka instrumen penelitian variabel aset memenuhi syarat untuk valid.

2. Variabel kewajiban diukur dengan 10 item pertanyaan. Setelah dilakukan uji realibilitas, nilai Cronbach alpha adalah 0,863 yang berarti variabel tersebut reliabel, karena memiliki Cronbach alpha diatas 0,60. Hasil uji validitas menunjukkan bahwa instrumen penelitian variabel kewajiban memiliki KMO-MSA sebesar 0,825, karena nilai KMO-MSA pada instrumen variabel kewajiban > 0.05 maka instrumen penelitian variabel kewajiban memenuhi syarat untuk valid.

3. Variabel ekuitas diukur dengan 10 item pertanyaan. Setelah dilakukan uji realibilitas, nilai Cronbach alpha adalah 0,814 yang berarti variabel tersebut reliabel, karena memiliki Cronbach alpha diatas 0,60. Hasil uji validitas menunjukkan bahwa instrumen penelitian variabel ekuitas memiliki 
KMO-MSA sebesar 0,772, karena nilai KMO-MSA pada instrumen variabel modal > 0.05 maka instrumen penelitian variabel modal memenuhi syarat untuk valid.

Pengujian normalitas data tersebut menggunakan One Sample Kormogorov Smirnov test, dengan syarat jika asym sig (2-tailed) $>0,05$ maka data tersebut berdistribusi normal. Sebaliknya jika asym sig (2-tailed ) <0,05 maka data

berdistribusi tidak normal

Berdasarkan hasil uji normalitas data dengan metode One Sample kolmogorov Smirnov test., untuk variabel aset menunjukkan nilai KolmogorovSmirnovZ sebesar 1,452 dengan signifikansi sebesar 0,030. Nilai Kolmogorov SmirnovZ untuk variabel kewajiban menunjukkan nilai 1,177 dengan signifikansi sebesar 0,125. Dan nilai Kolmogorov-SmirnovZ untuk variabel modal sebesar 1,267 dengan signifikansisebesar 0,081. Dapat dketahui bahwa seluruh variabel memiliki nilai Kolmogorov-SmirnovZ diatas 0,05, maka dapat disimpulkan bahwa seluruh variabel berdistribusi normal dan layak digunakan digunakan sebagai data penelitian.

\section{A. Uji Kruskall Wallis}

Pengujian hipotesis menggunakan uji data tiga sampel (independen) yang tidak berhubungan yaitu uji Kruskall Wallis,untuk mengetahui perbedaan pemahaman tentang aset, kewajiban, dan ekuitas antara mahasiswa yang berasal dari SMK jurusan akuntansi, SMA jurusan IPS, dan Madrasah Aliyah Umum.

Pengujian hipotesis dalam penelitian ini adalah sebagai berikut :

H1 : Terdapat perbedaan secara signifikan terhadap tingkat pemahaman aset antara mahasiswa berasal dari SMK
Jurusan Akuntansi, SMA Jurusan IPS dan Madrasah Aliyah Umum.

Variabel aktiva secara statistik chi-square tabel sebesar 124,342>chisquare hitung sebesar 2,077, sedangkan berdasarkan nilai probabilitas signifikansi sebesar 0,354 >0,05 maka H1 ditolak. Hasil tersebut menunjukkan bahwa tidak terdapat perbedaan secara signifikan terhadap pemahaman tentang aset antara mahasiswa yang berasal dari SMK Jurusan Akuntansi, SMA Jurusan IPS, dan Madrasah Aliyah Umum. Pada variabel aktiva mean rank tertinggi dimiliki oleh mahasiswa yang berasal dari Madrasah Aliyah dengan angka 56,21, dengan demikian maka dapat disimpulkan bahwa mahasiswa yang berasal dari Madrasah Aliyah lebih memahami tentang aset dibandingkan mahasiswa yang berasal dari SMA dan mahasiswa yang berasal dari SMK

Hasil ini mendukung penelitian terdahulu yang dilakukan Sar'i, Irsyadsyah, dan Djamil (2010) dan Novius (2010) yang menunjukkan bahwa pemahaman tentang aktiva antara mahasiswa Jurusan Akuntansi S1 UIN Suska Riau yang berasal dari SMK Jurusan Akuntansi, SMA Jurusan IPS, dan Madrasah Aliyah Umum tidaklah berbeda dan bisa dikatakan sama atau identik.

\section{H2 : Terdapat perbedaan secara signifikan terhadap tingkat pemahaman kewajiban antara mahasiswa berasal dari SMK Jurusan Akuntansi, SMA Jurusan IPS dan Madrasah Aliyah Umum. Variabel Kewajiban secara statistik chi-square tabel sebesar $124,342>$ chi-square hitung sebesar 1,653 , sedangkan berdasarkan nilai}


probabilitas signifikansi sebesar 0,438 > 0,05 maka H2 ditolak. Hasil tersebut menunjukkan bahwa tidak terdapat perbedaan secara signifikan terhadap pemahaman tentang Kewajiban antara mahasiswa yang berasal dari SMK Jurusan Akuntansi, SMA Jurusan IPS, dan Madrasah Aliyah Umum. Pada variabel aktiva mean rank tertinggi dimiliki oleh mahasiswa yang berasal dari Madrasah Aliyah dengan angka 55,02, dengan demikian maka dapat disimpulkan bahwa mahasiswa yang berasal dari Madrasah Aliyah lebih memahami tentang aktiva dibandingkan mahasiswa yang berasal dari SMA dan mahasiswa yang berasal dari SMK

Hasil ini mendukung penelitian terdahulu yang dilakukan Sar'i, Irsyadsyah, dan Djamil (2010) dan Novius (2010) yang menunjukkan bahwa pemahaman tentang kewajiban antara mahasiswa Jurusan Akuntansi S1 UIN Suska Riau yang berasal dari SMK Jurusan Akuntansi, SMA Jurusan IPS, dan Madrasah Aliyah Umum tidaklah berbeda dan bisa dikatakan sama atau identik.

\section{H3: Terdapat perbedaan secara signifikan terhadap tingkat pemahaman ekuitas antara mahasiswa berasal dari SMK Jurusan Akuntansi, SMA Jurusan IPS dan Madrasah Aliyah Umum.}

Variabel modal secara statistik chisquare tabel sebesar 124,342 > chisquare hitung sebesar 1,850, sedangkan berdasarkan nilai probabilitas signifikansi sebesar 0,397>0,05 maka H3 ditolak. Hasil tersebut menunjukkan bahwa tidak terdapat perbedaan secara signifikan terhadap pemahaman tentang ekuitasl antara mahasiswa yang berasal dari SMK Jurusan Akuntansi, SMA Jurusan IPS, dan Madrasah Aliyah
Umum. Pada variabel aktiva mean rank tertinggi dimiliki oleh mahasiswa yang berasal dari Madrasah Aliyah dengan angka 55,60, dengan demikian maka dapat disimpulkan bahwa mahasiswa yang berasal dari Madrasah Aliyah lebih memahami tentang aset dibandingkan mahasiswa yang berasal dari SMK dan mahasiswa yang berasal dari SMK.

Hasil ini tidak mendukung penelitian terdahulu yang dilakukan Sar'i, Irsyadsyah, dan Djamil (2010) yang menunjukkan bahwa pemahaman tentang modal antara mahasiswa Jurusan Akuntansi S1 UIN Suska Riau dan Universitas Riau yang berasal dari SMK Jurusan Akuntansi, SMA Jurusan IPS, dan Madrasah Aliyah Umum berbeda dan bisa dikatakan tidak sama., dan mendukung penelitian yang dilakukan Novius (2010) yang menunjukkan bahwa pemahaman tentang modal antara mahasiswa Jurusan Akuntansi S1 UIN Suska Riau yang berasal dari SMK Jurusan Akuntansi, SMA Jurusan IPS, dan Madrasah Aliyah Umum tidaklah berbeda

\section{Penutup}

Kesimpulan

Hasil penelitian mengenai analisis tingkat pemahaman mahasiswa akuntansi terhadap konsep dasar akuntansi setelah pemberlakuan IFRS (Studi Empiris Pada Mahasiswa Akuntansi Perguruan Tinggi Negeri di Pekanbaru), dengan jumlah responden 90 orang mahasiswa Jurusan Akuntansi Universitas Riau dan UIN Suska Riau. Dengan menggunakan yaitu uji Kruskal Wallis, yaitu mengetahui perbedaan pemahaman tentang aset, kewajiban dan ekuuitas antara mahasiswa berasal dari SMK Jurusan Akuntansi, SMA Jurusan IPS dan Madrasah Aliyah Umum, dinyatakan 
bahwa dinyatakan tidak terdapat perbedaan pemahaman mahasiswa terhadap konsep dasar akuntansi setelah pemberlakuan IFRS. Dan dari nilai mean rank ketiga variabel maka terlihat bahwa mahasiswa yang berasal dari Madrasah Aliyah lebih memahami konsep dasar akuntansi dibandingkan mahasiswa yang berasal dari SMK dan mahasiswa yang berasal dari SMA. Dengan demikian dapat disimpulkan bahwa penelitian ini menunjukkan tidak ada sebuah jaminan yang menyatakan bahwa mahasiswa yang berasal dari SMK jurusan akuntansi (SMEA Akuntansi) yang telah

\section{DAFTAR PUSTAKA}

Ariani, Rika, 2004, Persepsi Akuntan dan Mahasiswa Akuntansi Terhadap Karir di Kantor Akuntan Publik, Skripsi Program S-1, Universitas Bung Hatta, Padang. Arikunto, Suharsimi, 2002, Penelitian Suatu Pendekatan Khusus, Bina Aksara, Jakarta.

Herry dan Hamin, 2005, Tingkat Kepemilikan Manajerial dan Nilai Perusahaan: Bukti Empiris pada Perusahaan Publik di Indonesia, Ikatan Sarjana Ekonomi Indonesia (ISEI) Cabang Surabaya, Simposium Riset Ekonomi II, Surabaya.

Janes, Troy D, 2003, Accruals, Financial Distress, and Debt Covenants, Dissertation at the University of Michigan Business School. mendapat pembelajaran tentang akuntansi lebih banyak di sekolah mampu memahami mata kuliah dasardasar akuntansi dengan baik dibandingkan dengan mahasiswa yang berasal dari Madrasah Aliyah yang mendapat pembelajaran tentang akuntansi paling sedikit di sekolah.

Bagi peneliti selanjutnya agar menambahkan atau mengganti variabel penelitian dalam mengangkat permasalahan yang sama, seperti pemahaman jurnal, neraca, buku besar dan lainnya.

Munawir, S, 2004, Analisa Laporan

Keuangan, Penerbit Liberty, Yogyakarta.Nana, Sudjana, 2005, Dasar-Dasar Proses Belajar Mengajar, Bandung, Sinar Baru Algesindo.

Santoso, Singgih, 2004, Mengolah Data Statistik Secara Profesional Versi 10, Penerbit Elex Media Komputindo, Jakarta

Wina Sanjaya, 2005, Pembelajaran dalam Implemetasi Kurikulum Berbasis Kompetensi, Jakarta, Prenada Media.

IAI, 2009, Pernyataan Standar

Akuntansi Keuangan, Salemba, Jakarta

Weygandt, Kimmel, Kieso, 2012, Financial Accounting IFRS edition, John Wiley \& Sons, Inc., USA 
